\title{
14 Application of Municipal Sewage Sludge to Forest and Degraded Land
}

\author{
D. H. Marx, C. R. Berry, and P. P. Kormanik \\ USDA-Forest Service \\ Institute of Tree Root Biology \\ Athens, Georgia
}

Nearly 8 million dry tons (7 $256000 t$ ) of municipal sewage sludge are produced each year in the USA by the more than 15000 publicly owned treatment plants and the tonnage is increasing. Municipalities are faced with increasing cost of incineration, decreasing land for and increasing costs of landfills, and environmental concerns over ocean dumping. Under the circumstances, the attractiveness of sludge application for improvement of forest and degraded lands is obvious. About $25 \%$ of the municipal sludge being produced each year is being applied to land for its fertilizer and organic matter improvement value. For two decades, researchers in the USA have been studying the feasibility of land application of municipal sewage sludges. Research, large-scale practical projects, and commercial ventures have shown that stabilized sludge is an excellent organic amendment and chemical fertilizer for various plants. One disadvantage, however, is that sludge contains every element or compound found in wastes from domestic and industrial sources. Because of this, USEPA and ccrtain states have developed guidelines and regulations governing sludge application on human food crops. No federal guidelines have been issued for use on forests or animal food crops (Bastian et al., 1982; Sopper, 1992).

Forests occupy some 298 million of the 916 million hectares of land in the USA (Powell et al., 1993). Commercial timberlands occupy nearly 200 million hectares. The remaining forest is in parks, wilderness areas, and otherwise noncommercial land. Most of the commercial timberland is in the northern and southern regions, and about $60 \%$ is in private nonindustrial ownerships (Table 14-1).

One of the major ecological benefits of forests is their ability to absorb impure water, filter it, and release high-quality water to streams, rivers, and reservoirs. This water cycle is mediated by certain properties of the canopies, but mostly by the forest floor and soil. Must forest soils have high infiltration rates with negligible overland flow. Unlike other soils, forest soils

Conyright 1995 American Society of Agronomy, Crop Science Society of America, Soil Science Society of America, 677 S. Segoe Rd., Madison, WI 53711, USA. Agricultural Utilization of Urban and Industrial By-Products. ASA Special Puolication no. 58. 
Table 14-1. Commercial timberlands in the USA by ownership groun and region (Powell et al., 1993).

\begin{tabular}{lrrrrr} 
Region & $\begin{array}{c}\text { All } \\
\text { ownerships } †\end{array}$ & $\begin{array}{c}\text { National } \\
\text { forests }\end{array}$ & $\begin{array}{c}\text { Other } \\
\text { public }\end{array}$ & $\begin{array}{c}\text { Forcst } \\
\text { industry }\end{array}$ & $\begin{array}{c}\text { Nonindustrial } \\
\text { private }\end{array}$ \\
\cline { 2 - 6 } & & \multicolumn{5}{c}{ ha (thousands) } \\
North & 63885 & 3864 & 8405 & 6558 & 45058 \\
South & 80691 & 4678 & 3621 & 15800 & 56592 \\
Rocky Mountains & 25355 & 14738 & 2424 & 1181 & 7013 \\
Pacific Coast & 28267 & 10996 & 4509 & 4985 & 7777 \\
USA & 198198 & 34276 & 18959 & 28524 & 116440 \\
\hline
\end{tabular}

† Excludes over 100 million hectares of National Parks wilderness and other noncommercial forest lands.

have a well-defined floor of organic litter, large porous channels caused by roots and animal activity, high amounts of decomposing organic matter, and an accumulation of woody debris on the surface. Associated with these features is a perennial root system that supports diverse macro- and microorganisms in the forest floor, soil, and rhizosphere (i.e., fine root surfaces). These organisms disintegrate and decompose organic matter and release nutrient elements for eventual absorption by forest vegetation. Nutricnt and water cycles in forests are synchronous and interdependent.

The large forest land base in the USA and the physical, chemical and biological characteristics of forest soils make forests suitable for municipal sludge disposal. Additional advantages are that forests are of ten deficient in major nutrients found in sludges, and that forests are not major contributors to food chain crops for human consumption (Cole et al., 1983). Either liquid or solid (dewatered) sludges can be applied to forest stands of various ages or to harvested forest sites on which tree seedlings will soon be planted. Logic suggests that sludge application is best for sites with nutrient deficiencies or poor physical traits. There, the sludge is most likely to increase forest productivity and larger quantities of it can be applied than on sites of better quality. A considerable amount of research has been done in the USA since the early 1970 s on application of liquid and dewatered sludges to forest land. The results show that proper application is environmentally safe and increases forest productivity. Volumes have been published on this topic (Cole et al., 1983, 1986; Bledsoe, 1981; Smith \& Evans, 1977; Sopper \& Kardos, 1973).

Land has been degraded by mining for metal ores, coal, kaolin, phosphate, bauxite, gravel, and sand. Serious degradation also has been caused by erosion that follows improper land-use practices. Of the several million hectares of degraded land in the USA, most was originally forest. Degraded land is characterized by the absence of vegetation and animal communities, loss of topsoil either by erosion or by deliberate removal, low organic matter content, and poor hydrologic properties. Any one of these characteristics can limit casual revegetation attempts. Degradable land has few of the attributes of the original forest soil. Such land will not be revegetated through normal plant succession in a reasonable time frame. Accelerated revegetation requires a new root growth medium, artificial introduction of adapt- 
able plants, or alteration of soil physical, chemical, and microbiological conditions in which new plant communities can develop.

From 1930 through 1992, the mining industry extracted minerals from or deposited wastes on nearly 3.7 million hectares in 27 states in the USA. During this period, the mining industry reclaimed about 1.5 million hectares (Johnson \& Paone, 1981; U.S. Dep. Interior, 1992). Additional millions of hectares are in borrow pits, where soil was taken for construction of roads, dams, airports, and other improvements.

During the past $20 \mathrm{yr}$, researchers have created a large body of knowledge on the feasibility of using municipal sludge for the revegetation of degraded land. Recently, Sopper (1992) published an excellent review on this subject. He discussed the effects of sludge on vegetation growth response; physical, chemical, and biological properties of the mined soil; soil percolation and groundwater quality; and animal health and nutrition. He concluded that municipal sludges, if applied properly according to present guidelines, can be used to revegetate mined lands in an environmentally safe manner with no major adverse effects on the vegetation, soil, groundwater quality, or animal and human hcalth.

Since books have been published on the application of municipal sludges to forests and degraded lands in the USA, this chapter will cite only a few published studies as examples of this practice in the southeastern USA. $N$ of these studies were done at and funded by the Department of Energy (DOE), Savannah Riyer-Sita(SPS) A iken,South.Carolina, in cooperation with tht

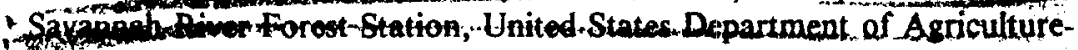
Forest Service (USDA-FS). Berry (1987) summarized results of many of these studies.

\section{BORROW PIT APPLICATIONS}

Many construction projects, such as dams, highways, and buildings require extensive earth fill to meet design criteria. When insufficient soil fill is available on the site it is necessary to "borrow" soil from another location. Generally, the entire A and B soil horizons have been removed from borrow pits. Compared with other disturbed areas such as surface mines, individual borrow pits may be relatively small, but collectively they represent a significant amount of surface area throughout the country. For exampls: borrow pits occupy about $1 \%$ of the DOE-SRS surface area of 81000 ha.

Blauch (1978) discusses the problems of borrow-pit reclamation. Prescriptions for effective reclamation vary considerably with differences in soil type, slope, desired vegetation, climatic conditions, and other factors. In the past, most borrow pit revegetation consisted of little more than a single application of fertilizer, perhaps some scarification of the surface soil, and sowing grass seed or planting tree seedlings. It is doubtful, however, that such a minimal effort ever resulted in satisfactory reclamation of a borrow pit. On the SRS, located in the upper Coastal Plain of South Carolina, a great deal more effort appears to be needed because the exposed clay sur- 
faces are highly compacted, eroded, impervious to rool penetration and growth, and extremely low in available water, fertility, and organic matter.

Early borrow pit studies at the SRS showed that various grasses responded to $\mathrm{N}$ and $\mathrm{P}$ fertilization but not to K or lime anplications (Granade, 1976). Planted slash and loblolly pine (Pinus elliottii Engelm. and P. taeda L.) seedlings responded to ammonium sulfate applications (McGregor \& Goebel, 1968). However, the effects of these treatments lasted only a few growing seasons, then soil nutrients were depleted and plant growth slowed.

Three experiments were conducted on a large borrow pit at the SRS in 1976 to 1977. The borrow pit, which originally had Fuquay (loamy, siliceous, themic Arenic Plinthic, Kandiudults) and Wagram (loamy, siliceous, themic Arenic, Kandiudults) soils, was created in 1950 to 1952 by removing 2 to $6 \mathrm{~m}$ of soil leaving exposed a heavy clay. In 1953, reclamation was attempted by planting loblolly pine seedlings. In 1976, surviving trees were severely stunted, yellow, and their roots barely penetrated the soil surface. Many surviving trees were windthrown, but those still standing were only 2.5 to $5 \mathrm{~m}$ tall. Many standing trees had such limited root development and soil penetration that they cnuld readily be pulled from the soil by hand. Although a thin layer of litter was present under some trees, no understory grasses or shrubs were growing to retard rapid surface runoff. The site was cleared of trees, subsoiled $0.9 \mathrm{~m}$ deep in opposing directions on 1.2 -m centers, and doubledisked. Municipal sludge used for the three studies had undergone secondary treatment with anaerobic digestion and sand-bed drying. It was obtained from treatment plants in Athens, Georgia, and contained about $2 \% \mathrm{~N}, 1 \%$ $\mathrm{P}, 0.5 \% \mathrm{~K}, 50 \%$ organic matter and less than $10 \mathrm{mg} \mathrm{kg}^{-1} \mathrm{Cd}$ and $250 \mathrm{mg}$ $\mathrm{kg}^{-1} \mathrm{Zn}$ on a dry weight basis.

In the first study (Berry \& Marx, 1980), sludge application was compared to fertilizer $\left(560 \mathrm{~kg} \mathrm{ha}^{-1}\right.$ of $\left.10-1,-10\right)$ and lime $\left(22.42 \mathrm{~kg} \mathrm{ha}^{-1}\right.$ dolomitic IImestone). Tree bark or bottom furnace ash treatments were applied to each of these. Sludge, bark and ash werc applied at a rate of $125 \mathrm{~m}^{3}$ $h^{-1}$, or approximately $1.3 \mathrm{~cm}$ deep. For sludge, this rate was equal to 34 $\mathrm{Mg} \mathrm{ha}^{-1}$ dry weight. After disking in amendments, the entire area was seeded to fescue (Festuca arundinacea Schreb.) in the fall of 1975 and planted the following spring with loblolly pine seedlings. Half of the seedlings had ectomycorrhizae formed naturally in the nursery, and half had Pisolithus tinctorius (Pers.) Coker \& Couch ectomycorrhizae resulting from nursery soil inoculation (Marx et al., 1984).

After $3 \mathrm{yr}$, the effect of sludge overwhelmed effects of other amındments and specific ectomycorrhizae (Fig. 14-1). Seedlings without $P$. tinctorius ectomycorrhizae at planting formed this specific ectomycorrhiza from indigenous inoculum on site and thus precluded any ectomycorrhizal treatment effect. Seedling volumes (diameter squared times height, $D^{2} H$ ) were 28 times greater and grass biomass was five times greater on sludge plots than on nonsludge plots (Berry \& Marx, 1980). At age five, the plots were thinned by removing every other tree. Fescue was no longer present in any plots by age five because canopy closure in sludge plots reduced light significantly and nonsludge plots were nutrient deficient. Trees in sludge plots af- 


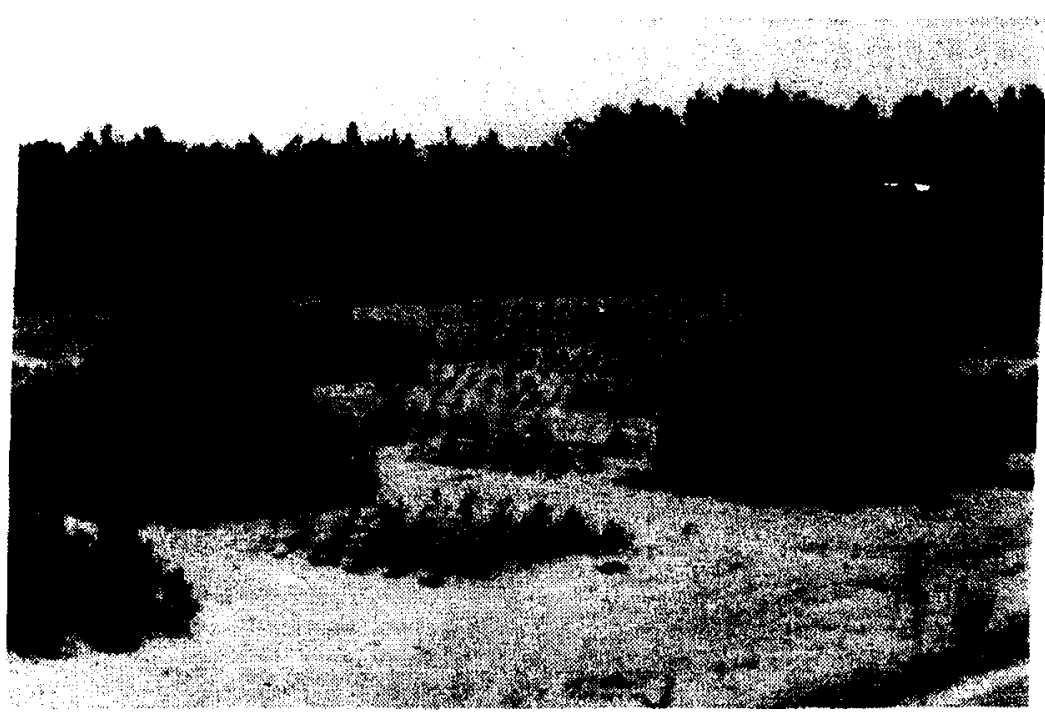

Fig. 14-1. Response of loblolly pine after 3 yr to amendments of municipal sewage sludge to a borrow pit in South Carolina. Stunted trees are growing in plots receiving a variety of other amendments and tertilizers but no sludge.

ter $10 \mathrm{yr}$ were still dramatically larger in volume than trees on nontreated control and fertilized and limed plots (Berry, 1987). Compared to other plots, soils in sludge plots had more than two times as much N, more than 25 times as much $P$, and nearly three times more cation exchange capacity (CEC) and organic matter in the upper $20 \mathrm{~cm}$ of soil (Tabl: 14-2). Increase in CEC was likely due to increased organic matter. Fertilizer and lime treatments were identical to control plots except for more $\mathrm{Ca}$ and $\mathrm{Mg}$. We remeasured these trees at age 18 (October 1993), and found sludge effects persisting. Sludge increased tree volumes by more than 80 -fold over those in control plots (Table 14-2). Trees in fertilized and limed plots were 10 times larger than control trees. Using standard site index curves, we estimatc that trees on sludge plots will have a height for $60 \mathrm{ft}(18.3 \mathrm{mI})$ at age 25 (site index 60$)$. On nonsludge plots, tree heights suggest that site index at age 25 will be 30 for the fertilized and limed plots and less than 20 for the nontreated control plots. In examining the age 3,10 , and 18 data, it becomes evident that the fertilizer and lime treatment effects have slowed considerably whereas sludge is still contributing to rapid growth after $18 \mathrm{yr}$.

In the second loblolly pine study on this borrow pit, treatments were the same as the first except that bark and ash were not used and the nonamended control was not included. Other treatments were containergrown pine seedlings with Pisolithus, Thelephora terrestris (Ehrh.) Fr., or no ectomycorrhizae at planting (Ruehle, 1980). This study differed from the first in that seedlings were planted in the fall of 1977 rather than the spring of 1976. Amendments in this study were in soil without trees for two grow- 
Table 14-2. Growth of loblolly pine after $18 \mathrm{yr}$ and soil chemical properties after $10 \mathrm{yr}$ on a borrow pit amended with sludge or fertilizer plus lime (Berry \& Marx. 1980; Berry, 1978).

\begin{tabular}{|c|c|c|c|c|c|c|c|c|}
\hline \multicolumn{9}{|c|}{ Growth measurements after $18 \mathrm{yr}^{*}$} \\
\hline \multirow[t]{2}{*}{ Treatment } & \multicolumn{2}{|c|}{ Height } & \multicolumn{2}{|c|}{$\mathrm{DBH}$} & \multicolumn{2}{|c|}{ Tree volume } & \multicolumn{2}{|c|}{ Sile indext } \\
\hline & \multicolumn{2}{|r|}{$\mathbf{m}$} & \multicolumn{2}{|c|}{$\mathrm{cm}$} & \multicolumn{2}{|c|}{$\mathrm{cm}^{3} \times 10^{3}$} & \multirow{2}{*}{\multicolumn{2}{|c|}{$\begin{array}{r}>20 \\
30 \\
<60\end{array}$}} \\
\hline $\begin{array}{l}\text { Controlt } \\
\text { Fertilizer \& lime } \\
\text { Sludge }\end{array}$ & \multicolumn{2}{|c|}{$\begin{array}{r}4.1 \mathrm{c} \\
6.2 \mathrm{~b} \\
13.8 \mathrm{a}\end{array}$} & \multicolumn{2}{|c|}{$\begin{array}{r}3.9 \mathrm{c} \\
7.5 \mathrm{~b} \\
15.4 \mathrm{a}\end{array}$} & \multicolumn{2}{|c|}{$\begin{array}{r}4 c \\
44 b \\
336 a\end{array}$} & & \\
\hline Sludge & \multicolumn{6}{|c|}{ Soil chemical properties $(0-20 \mathrm{~cm})$ after $10 \mathrm{yr}^{*}$} & & \\
\hline \multirow[t]{2}{*}{ Treatment } & $N$ & $\mathrm{P}$ & $\mathrm{K}$ & $\mathrm{Ca}$ & M.g & $\mathrm{pH}$ & CEC & OM \\
\hline & $\ldots$ & - & $\operatorname{lgg}^{-1}$ & $\ldots$. & - & c mol & $g^{-1}$ & $\mathrm{~g} \mathrm{~kg}^{-1}$ \\
\hline $\begin{array}{l}\text { Controlf } \\
\text { Fertilizer \& lime§ } \\
\text { Sludge }\end{array}$ & $\begin{array}{l}174 \mathrm{~b} \\
142 \mathrm{~b} \\
390 \mathrm{a}\end{array}$ & $\begin{array}{r}2 b \\
2 b \\
55 a\end{array}$ & $\begin{array}{l}30 b \\
35 b \\
49 a\end{array}$ & $\begin{array}{r}29 \mathrm{c} \\
103 \mathrm{a} \\
76 \mathrm{~b}\end{array}$ & $\begin{array}{l}17 \mathrm{~b} \\
59 \mathrm{a} \\
22 \mathrm{~b}\end{array}$ & $\begin{array}{l}4.5 \mathrm{ab} \\
4.9 \mathrm{a} \\
4.3 \mathrm{~b}\end{array}$ & $\begin{array}{l}1.5 b \\
1.9 b \\
4.4 a\end{array}$ & $\begin{array}{r}3 b \\
5 b \\
13 b\end{array}$ \\
\hline
\end{tabular}

* Within columns, means sharing a common letter do not differ significantly at $P=0.05$.

t Estimated height in feet at age $25 \mathrm{yr}$.

¥ Subsoiled one dircetion $2.5 \mathrm{~m}$ apart, disked and planted.

Subsoiled, $560 \mathrm{~kg} \mathrm{ha}^{-1}$ of $10-10 \cdot 10$ fertilizer and $2242 \mathrm{~kg} \mathrm{ha}^{-1}$ dolomitic limestone

broadcast, disked and planted.

Subsoiled, $34 \mathrm{Mg} \mathrm{ha}^{-1}$ (dry wt) dewatered sludge broadcast. disked and planted.

ing seasons and a winter $(15 \mathrm{mo})$ compared to only the winter for the first study.

Two years after planting on sludge-amended plots, seedlings initially with Pisolithus ectomycorrhizae had greater height, root-collar diameter, and seedling volume $\left(D^{2} H\right)$ than seedlings with no mycorrhizae or Thelephora ectomycorshizac at planting (Fig. 14 2). Pisolithus seedlings had nearly four times more volume than other seedlings (Table 14-3). On fertilized plots, seedlings with Pisolithus ectomycorrhizae were larger than controls. There was no difference in survival among mycorrhizal treatments on the sludge plots.

After averaging the ectomycorrhizal treatments in the amendment treatments, the sludge effect on growth was over 20 times that of fertilizer and lime. The reason is that sludge plots had more than four times the $\mathrm{N}$, ninc times the $P$, and four times the organic matter found in the fertilizer and lime plots after $2 \mathrm{yr}$ of tree growth and $3 \mathrm{yr}$ of fescue growth. The poor growth performance of seedlings initially free of ectomycorrhizae shows again the importance of ectomycorrhizae on seedlings at planting, especially on stressed sites. The value of the stress adapted ectomycorrhizal fungus, $P$. tinctorius, in the sludge-amended soils also was demonstrated in this study. Apparent$y$, the long time between adding amendments and seedling planting reduced the indigenous inoculum of $P$. tinctorius on the site so that ectomycorrhizal integrity was maintained on seedlings. The loss of integrity of the ectomycorrhizal treatments in the first study was attributed to indigenous $P$. tinctorius inoculum. 

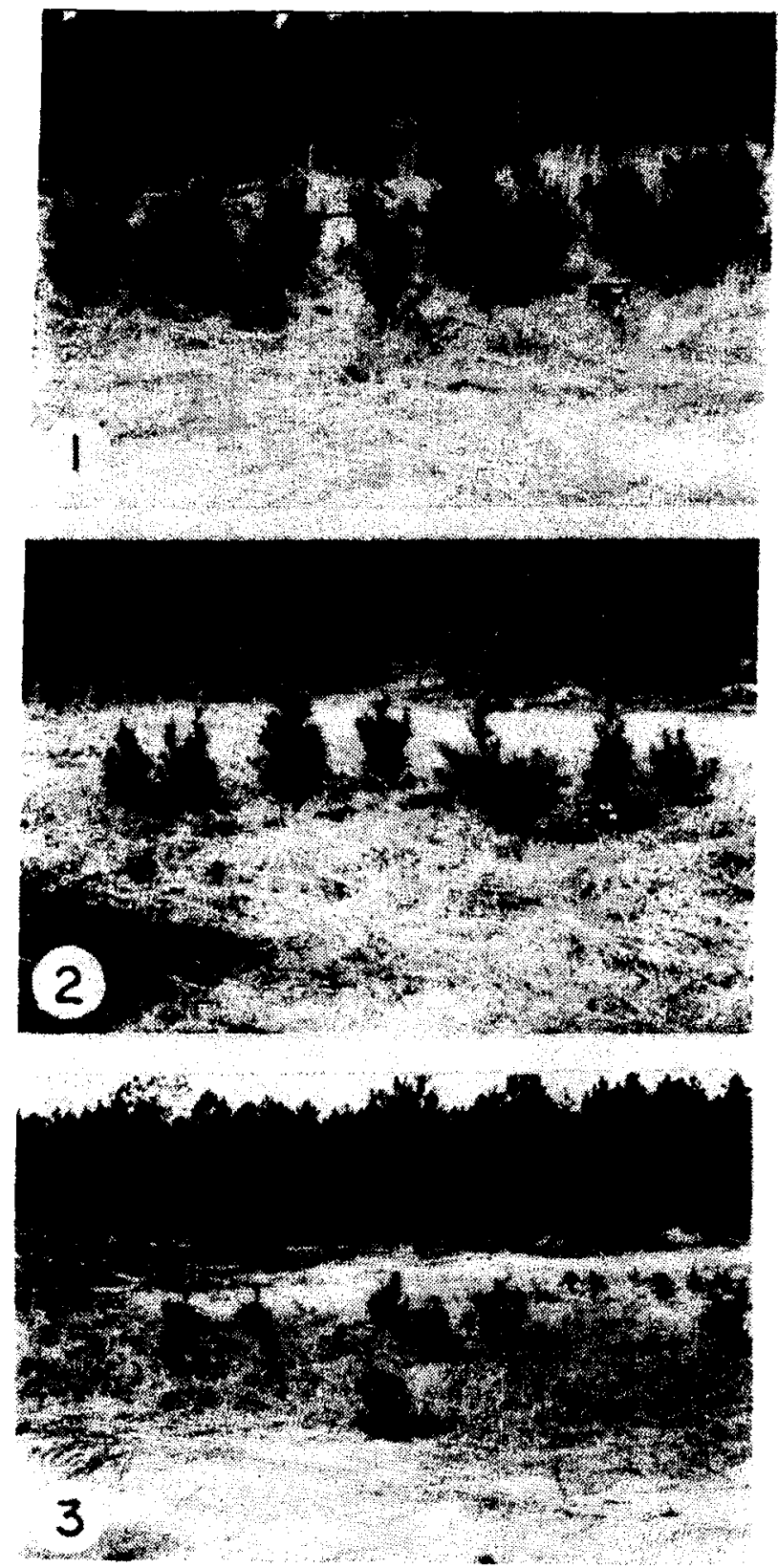

Fig. 14-2. Response of loblolly pine with specific ectomycorrhizae after 2 yr on a borrow pit amended with municipal sewage siudge int South Carolina. Seedlings had eclomycorthizac formed by Pisolithus tinctorius (1), Thelephora terrestris (2), or no ectomycorrhizae (3) al plarring. 
Table 14-3. Survival and growth of containerized loblolly pine seedlings with specific ectomycorrhizae and soil chemical properties after 2 yr on a borrow pit amended with sludge and fertilizer and lime (Ruehl, 1980). $\dagger$

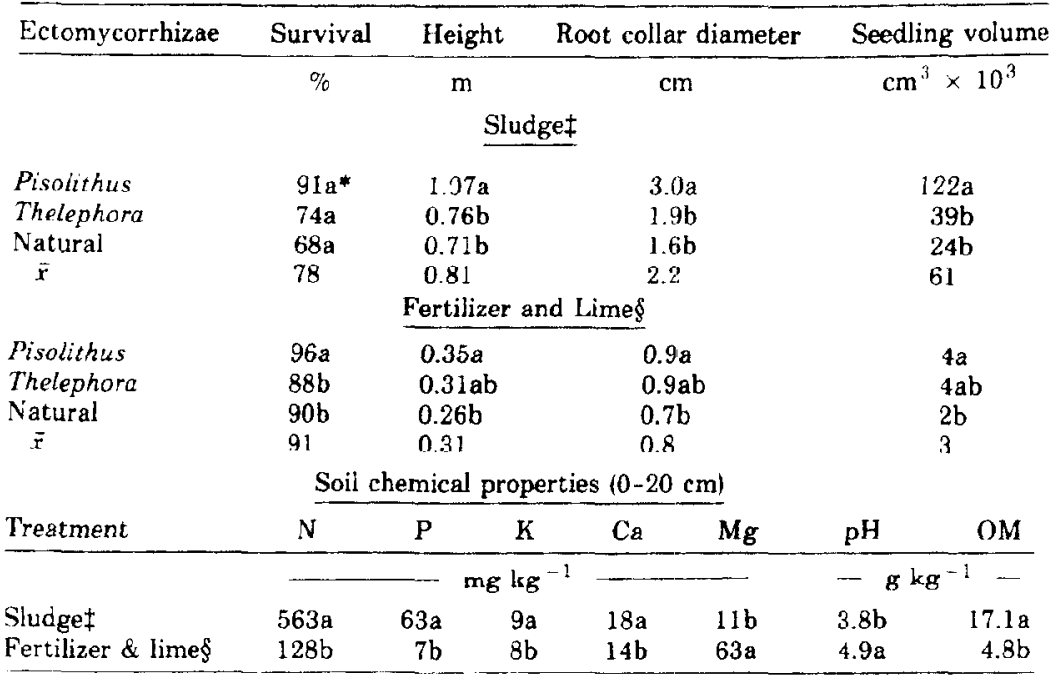

* Within columns and amendment groups, means followed by a common letter do not differ significantly at $P=0.05$.

† Except for survival, all seedling measurements in sludge plots were significantly larger than those in fertilizer \& lime plots.

† Subsoiled two directions $1.2 \mathrm{~m}$ apart, $34 \mathrm{Mg} \mathrm{ha}^{-1}$ (dry wt) dewatered sludge broadcast. disked and planted 15 mo later.

$\S$ Subsoiled, $560 \mathrm{~kg} \mathrm{ha}^{-1}$ of $10-10-10$ fertilizer and $2242 \mathrm{~kg} \mathrm{ha}^{-1}$ dolomitic limestone broadcast, disked and planted 15 mo later.

In the third study on this borrow pit, $0,17,34$, or $68 \mathrm{Mg} \mathrm{ha}^{-1}$ of sludge were applied and incorporated as in the other studies. Plots were planted to sweetgum (Liquidambar styraciflua L.) in late winter of 1976.

Duing the first 5 yr (Kormanik \& Schultz, 1985), sludge treatments sig nificantly improved establishment of fescue and growth of sweetgum. However, all combinations of fescue with sludge significantly reduced 1 styr survival of sweetgum. probably due to competition with fescue. Fifth-year height growth of sweetgum on the nonamended plots was only $0.7 \mathrm{~m}$. On plots amended at even the lowest rate of sludge, height growth exceeded 2.75 $\mathrm{m}$ (Fig. 14-3). Heights (approximately $3.6 \mathrm{~m}$ ) after $5 \mathrm{yr}$ on plots amended at the highest sludge rate were equal to or greater than 5-yr heights reported for sweetgum on good quality reforestation sites (Kormanik, 1990). After 10 yr (Berry, 1987), treatment ranking remained the same but differences in growth were greater (Table 14-4). The lowest amount of sludge increased seedling volumes by 18 times over that of controls. The two highest amounts of sludge increased volumes by over 35 times and did not differ from each other. Soil chemical properties after 10 yr showed the fertilizer value and soil improvement effects of sludge (Table 14-4). As in the other studies, sludge amendments improved amounts of $\mathrm{N}, \mathrm{P}, \mathrm{K}$, and organic matter. Cation ex- 


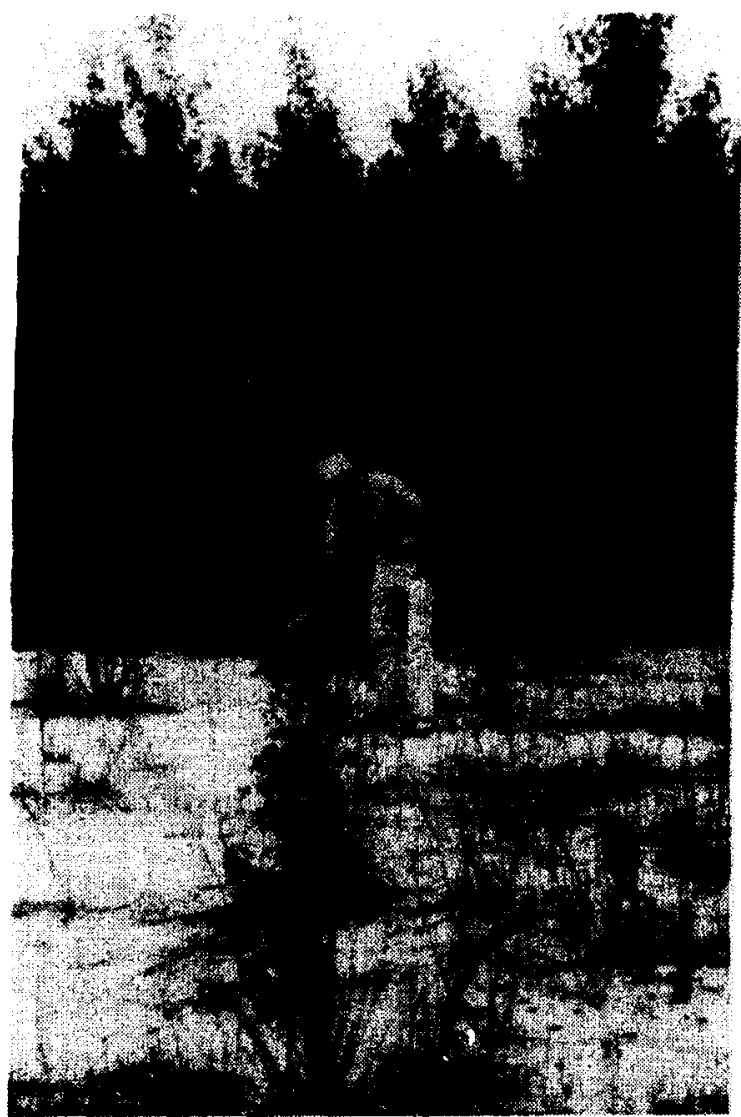

Fig. 143 . Response of sweetgum after 5 yr in amendments of municinal sewage sludge to a borrow pit in South Carolina. Stunted trees in foreground are growing in fertilizer and lime ploss. Iarge trees in background are growing in sludge plots.

change capacity was increased by four times in the lowest sludge treatment and by more than six times in the two highest treatments, these increases were correlated with increases in organic matter. Sludge application increased $\mathrm{N}$ by nearly five times and $\mathrm{P}$ by 13 to 36 times, depending on the amount applied.

If the soil is compacted or has a shallow hardpan or other impervious subsoil layer, deep subsoiling is considered essential preparation for the establishment of trees. This practice is currently being used on reforestation sites and on degraded lands in the USA and other parts of the world (Berry, 1985). In 1979, a subsoiling and sewage sludge study with loblolly pine was installed on another borrow pit at the SRS. This site was originally overlain with Gunter sand (fine loamy, mixed thermic Aeric Ochruults), but removal of several meters of soil exposed a highly compacted deep clay. The stunted 
Table 14-4. Growth of sweetgum and soil chemical properties after 10 yr on a borrow pit amended with different amounts of sewage sludge (Kormanik \& Schultz, 1985; Berry. 19871.

\begin{tabular}{|c|c|c|c|c|c|c|c|c|}
\hline \multicolumn{9}{|c|}{ Growth measurements after $10 \mathrm{yr}^{*}$} \\
\hline \multirow[t]{2}{*}{ Treatment } & \multicolumn{3}{|c|}{ Height } & \multicolumn{3}{|c|}{ Root collar diameter } & \multicolumn{2}{|c|}{ Tree volume } \\
\hline & \multicolumn{3}{|c|}{$\mathrm{m}$} & \multicolumn{3}{|c|}{$\mathrm{cm}$} & \multicolumn{2}{|c|}{$\mathrm{cm}^{3} \times 10^{2}$} \\
\hline $\begin{array}{l}\text { Controlt } \\
17 \mathrm{Mg} \text { /hat } \\
34 \mathrm{Mg} / \text { hat } \\
68 \mathrm{Mg} / \text { hat }\end{array}$ & \multicolumn{2}{|r|}{$\begin{array}{l}0.63 c \\
4.11 b \\
5.49 a \\
5.57 a\end{array}$} & & \multicolumn{3}{|c|}{$\begin{array}{r}3.6 \mathrm{~b} \\
8.6 \mathrm{a} \\
10.6 \mathrm{a} \\
10.8 \mathrm{a}\end{array}$} & \multicolumn{2}{|r|}{$\begin{array}{r}2 c \\
36 b \\
71 a \\
74 a\end{array}$} \\
\hline \multicolumn{9}{|c|}{ Soil chemical properties after $10 \mathrm{yr}^{*}$} \\
\hline \multirow[t]{2}{*}{ Treatment } & $\mathrm{N}$ & $\mathbf{P}$ & $\mathrm{K}$ & $\mathrm{Ca}$ & $\mathrm{Mg}$ & pH & $\mathrm{CEC}$ & $\mathrm{OM}$ \\
\hline & \multicolumn{5}{|c|}{$\mathrm{mg} \mathrm{kg}^{-1}$} & \multicolumn{2}{|c|}{$\mathrm{c} \mathrm{mol} \mathrm{kg}^{-1}$} & $\mathrm{~g} \mathrm{~kg}^{-1}$ \\
\hline $\begin{array}{l}\text { Control } t \\
17 \mathrm{Mg} \text { haf } \\
34 \mathrm{Mg} \text { /haf } \\
68 \mathrm{Mg} / \text { ha } f\end{array}$ & $\begin{array}{l}102 \mathrm{~b} \\
368 \mathrm{a} \\
492 \mathrm{a} \\
596 \mathrm{a}\end{array}$ & $\begin{array}{l}2 c \\
26 b \\
43 b \\
72 a\end{array}$ & $\begin{array}{l}33 b \\
47 a \\
46 a \\
52 a\end{array}$ & $\begin{array}{l}65 a \\
65 a \\
58 a \\
76 a\end{array}$ & $\begin{array}{l}21 a \\
17 a \\
15 a \\
21 a\end{array}$ & $\begin{array}{l}4.6 \mathrm{a} \\
4.4 \mathrm{~b} \\
4.2 \mathrm{~b} \\
4.2 \mathrm{~b}\end{array}$ & $\begin{array}{l}1.3 \mathrm{c} \\
5.6 \mathrm{~b} \\
7.9 \mathrm{a} \\
7.9 \mathrm{a}\end{array}$ & $\begin{array}{r}3 c \\
9 b \\
13 a \\
14 a\end{array}$ \\
\hline
\end{tabular}

* Within columns, means sharing a common letter do not differ significantly at $P=0.05$. Subsoiled two directions $1.2 \mathrm{~m}$ apart, disked and planted.

I Suhsoiled, dewatered sludge broadcast at 17,34 , or $68 \mathrm{Mg}$ ha ${ }^{\cdots 1}$ lequivalent to 0.64 1.27 , or $2.54-\mathrm{cm}$ deep) disked and planted.

pines, planted 20 yr earlier, were removed with a bulldozer. Nine soil physical tuealments were installed separately on plots amended with $17 \mathrm{Mg} \mathrm{ha}^{-1}$ sludge and $1120 \mathrm{~kg} \mathrm{ha}^{-1}$ of fertilizer and $2242 \mathrm{~kg} \mathrm{ha}^{-1}$ of lime. Physical treatments involved ripping soil to 45 - or $90-\mathrm{cm}$ depths, ripping on 1.1 - or $2.2-\mathrm{m}$ centers, or ripping in one direction or two opposing directions, and disking only. Half as much sludge and twice as much fertilizer and lime were applied as in the previous loblolly pine study. The source and chemical composition of the sludge were the same as the other borrow pit studies. Seedlings with abundant $P$. tinctorius ectomycorrhizae were planted on all plots in late winter 1979.

Root systems of several trees were excavated after 2 yr (Fig. 14-4). In all eases, root penetration was only as decp as the depth of tillage, $20 \mathrm{~cm}$ for disked plots and 45 or $90 \mathrm{~cm}$ for subsoiled plots (Berry, 1987). After 4 $\mathrm{yr}$, trees on sludge plots grew an average of $37 \%$ more in height and $76 \%$ more in diameter breast height (DBH) than trees on fertilizer plots. Trees grew faster on fertilizer plots subsoiled $45 \mathrm{~cm}$ deep than on plots subsoiled $90 \mathrm{~cm}$ deep. Apparently, there was more leaching of nutrients and more available water in the deeper trenches. On sludge plots, trees grew faster when subsoiled $90 \mathrm{~cm}$ deep than when subsoiled $45 \mathrm{~cm}$ deep. Other variations in subsoiling, i.e., distance between furrows and whether in one direction or two, had little effect on growth of trees at this time. On sludge plots, all subsoiling treatments produced better growth than disking. Production of herbaceous biomass was significantly greater on sludge plots and on subsoiled fertilizer plots than on fertilizer plots that had only been disked.

At age seven (Berry, 1987), the sludge effect was still dominant. Regardless of soil physical treatments, trees on sludge plots had four times more 


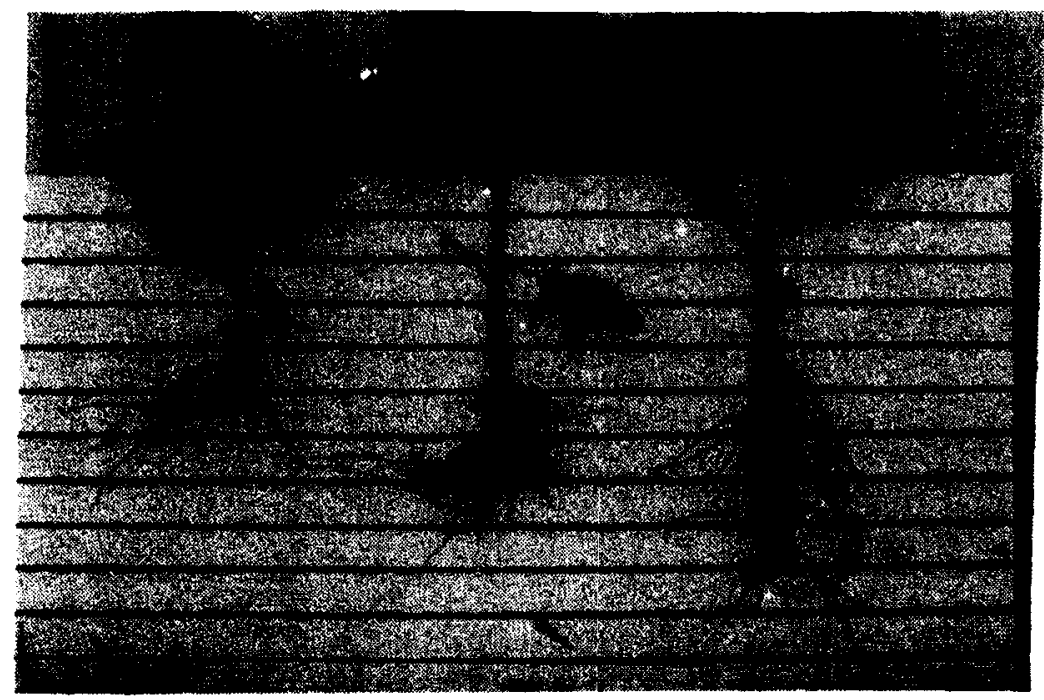

Fig. 14-4. Above- and belowground response of loblolly pine after 2 yr to subsoiling in a borrow pit amended with municipal sewage sludge in South Carolina. Seedling on left is from a disced (20-em-deep) plot. Seedlings in the middle and right are from plots subsoiled 45 and $90-\mathrm{cm}$ deep, respectively.

volume than those on fertilizer and lime plots. Any type of subsoiling improved trec volumes by 30 to $50 \%$ compared to the disked treatment. Sludge plots at age seven had more than two times as much $\mathrm{N}, 10$ times more P, twice the organic matter content, and three times the CEC as plots that were fertilized (Table 14-5). Subsoiling did not affect soil chemical properties. By this time, essential nutrients from the fertilizer treatment were tied up in biomass and quantities remaining in the soil were not sufficient to maintain appreciable growth rates of trees. At age 14, we remeasured these trees. Tree volumcs on sludge plots were five to six times greater than on fertilizer plots (Table 14-5). Depth of subsoiling also had significant effects on the sludge plots. Generally, sludge more than doubled the site index on this borrow pit. Not shown in Table 14-5 is windthrow. Few trees were windthrown or severely leaning on the subsoiled plots as compared to the disked plots. Improved tree anchorage due to deep root penetration following subsoiling is vital for long-term maintenance of trees on degraded lands such as borrow pits. A single heavy application of fertilizer and lime does little to maintain tree growth over the long term (i.e., 5-10 yr). Sludge, even at only 17 $\mathrm{Mg} \mathrm{ha}^{-1}$, can maintain growth for this period. However, twice this amount, as used in the earlier studies, assures greater tree productivity for a longer period due to greatly improved soil chemical properties. 
Table 14-5. Growth of loblolly pine after 14 yr and soil chemical properties after 7 yr on a borrow pit amended with sludge or fertilizer plus lime and subsoiled to different depths (Berry, 1985, 1987).

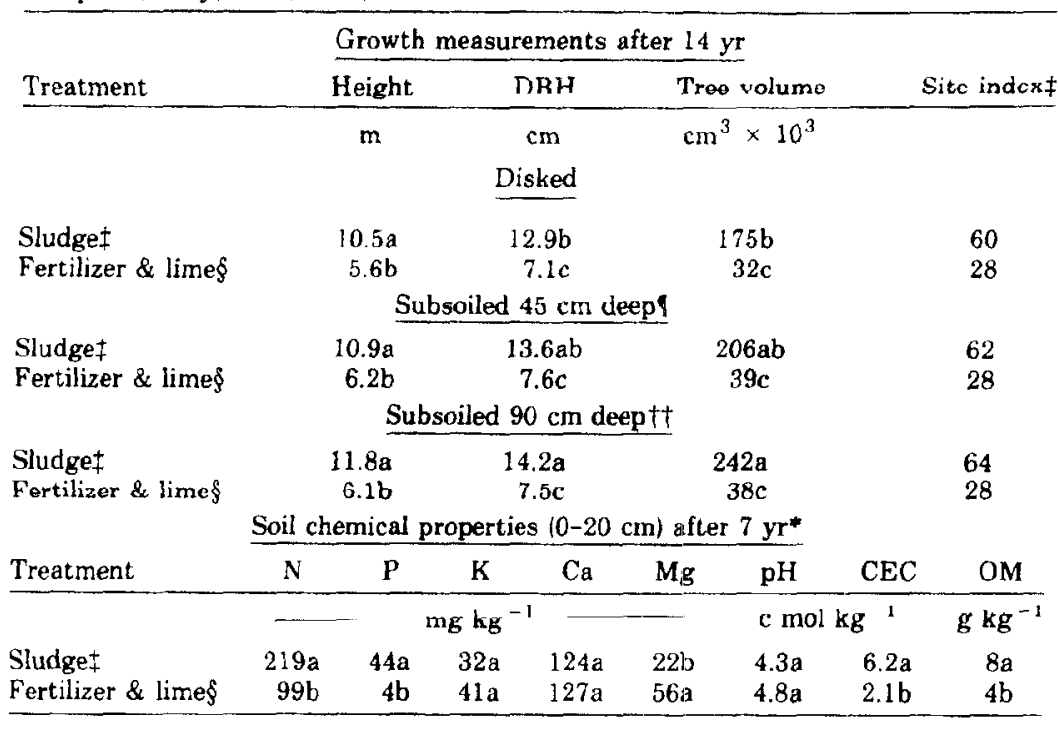

* Within columns, means sharing a common letter do not differ significantly at $P=0.05$.

† Estimated height in feet at age $25 \mathrm{yr}$.

Subsoiled, $17 \mathrm{Mg} \mathrm{ha}^{-1}$ (dry wt) dewatered sludge broadcast, disked and planted.

$\S$ Subsoiled, $1121 \mathrm{~kg} \mathrm{ha}^{-1}$ of $10-10-10$ fertilizer and $2242 \mathrm{~kg} \mathrm{ha}^{-1}$ dolomitic limestone broadcast, disked and planted.

Subsoiled $45 \mathrm{~cm}$ deep, two directions on $1.3 \cdot \mathrm{cm}$ centers.

t+ Subsoiled $90 \mathrm{~cm}$ deep, two directions on $1.3 \mathrm{~cm}$ centers.

\section{ERONFD I.ANDS APPLICATION}

The Tennessee Copper Basin is unique in the eastern USA in that the original mixed stands of oak and pine were eliminated on nearly 3000 ha and the surrounding 7000 ha were reduced to grasslands in the mid-to-late 1800 s by air pollution resulting from primitive copper ore smelting. Trees were cut to produce fuel for heap roasting of iron pyrite ore. This process emitted $\mathrm{SO}_{2}$ fumes, which killed remaining trees and natural regencration from stump sprouts and seeds. Severe erosion of topsoil left deep gullies over thousands of hectares. Through the early 1970s, chronic air pollution continued to retard growth and reduce survival of trees planted by various agencies. Due to innovations in ore processing, $\mathrm{SO}_{2}$ emissions rarely occur today. However, even with clean air, several other obstacles to reforestation exist. The surface soil is void of essential nutrients, organic matter, associated beneficial microorganisms, and compacted textural layers are present at shallow depths. Retention of soil water is low, and dry winds severely dessicate planted trees.

The Basin is in the transition zone between the Blue Ridge and Ridge and Valley physiographic provinces. It has a humid, mesothermal climate. 
Soils are principally Hapludults with some Palenaults. Since the mid-1970s, various techniques have been svaluated for reforesting the degraded Basin. Berry and Marx (1978) nearly doubled volumes of planted loblolly pine and Virginia pine ( $P$. virginiana Mill.) after two growing seasons by planting seedlings with $P$. tinctorius ectomycorrhizae. Berry (1979) also found that a $90 \mathrm{~g}$ pellet of dried sewage sludge or a $9-\mathrm{g}$ or $21 \mathrm{-g}$ commercial fertilizer tablet applied in the seedling closing-hole stimulated volume growth of loblolly pine by 87,103 , and $208 \%$, respectively after $2 \mathrm{yr}$. None of these spot applications, however, had long-term effects on growth.

In the most significant study in the Basin, sludge was broadcast and incorporated into the soil (Berry, 1982). The study was installed on a severely eroded hilltop with less than 3\% slope. Sludge from Athens, Georgia, comparable in chemical content to that described earlier, was broadcast at a rate of $34 \mathrm{Mg} \mathrm{ha}{ }^{-1}$ before subsoiling 0.7 deep on $1.2-\mathrm{m}$ centers and disking. For comparison, fertilizer (10-10-10 analysis) at $900 \mathrm{~kg}^{\mathrm{ka}}{ }^{-1}$ and burnt lime $(\mathrm{CaO})$ at $1400 \mathrm{~kg} \mathrm{ha}^{-1}$ were applied and incorporated identically. The entire site was seeded to fescue and planted at high density $(9000$ seedlings $\mathrm{ha}^{-1}$ ) to loblolly, Virginia, and shortleaf ( $P$. echinata Mill.) pine seedlings in the spring of 1975 . High-density planting of trees allows rapid domination of the prepared site, excludes undesirable vegetation by early canopy closure, obtains maximum utilization of soil amendments with rapid root closurc, and controls erosion by reducing the velocity of rain through the closed canopy. Results after 4 yr (Berry, 198.2) were as dramatic as those from the borrow pits. Sludge application increased tree volumes by more than four times on loblolly pine plots and more than three times on plots of the two other pine species. Distribution of aboveground biomass of the trees was affected by sludge at age five. McNab and Berry (1985) found that the proportion of total tree weight in wood was $8 \%$ higher on sludge plots than on others. The proportion of tree weight in foliage was lower on sludge plots. That difference suggests a greater photosynthetic efficiency of proportionally less foliage for trees growing in the sludge-amended soil or more allocation to roots in nonamended snils. Rerry (1987) remeasured these trees and analyzed soil at age 10 and found the effect of the sludge still evident (Table 14-6). Tree volumes on sludge plots were still three to four times greater than on fertilizer plots for all pine species. Sludge plots contained twice as much $N$, three times as much organic matter and five times as much $\mathrm{CEC}$. Soil $\mathrm{P}$ in the fertilizer plots after $10 \mathrm{yr}$ was only $1 \mathrm{mg} \mathrm{kg}^{-1}$, sludge plots had $18 \mathrm{mg} \mathrm{kg}^{-1}$. There is little doubt that on such impoverished sites as the Copper Basin, sewage sludge helps to restore needed vegetation. Nevertheless, because of the public fear of sludge and its high transportation cost, sludge is not being used to reclaim the Copper Basin. Subsoiling on contour, application of inorganic fertilizer, and planting $\mathrm{N}$-fixing trees are having some success in the Copper Basin.

Littleleaf disease is the most serious disease of shortleaf pine. The feeder root pathogen Phytophthora cinnamomi Rands, and other Pythiaceous fungi and nematodes are the biological causal agents (Otrosina \& Marx, 1975). Severe erosion of surface soil also is a cause. This disease occurs on eroded 
Table 14-6. Growth of pines and soil chemical properties after $10 \mathrm{yr}$ on a severely eroded site in the Tennessee Copper Basin amended with sludge or fertilizer plus lime (Berry, 1982, 1987).

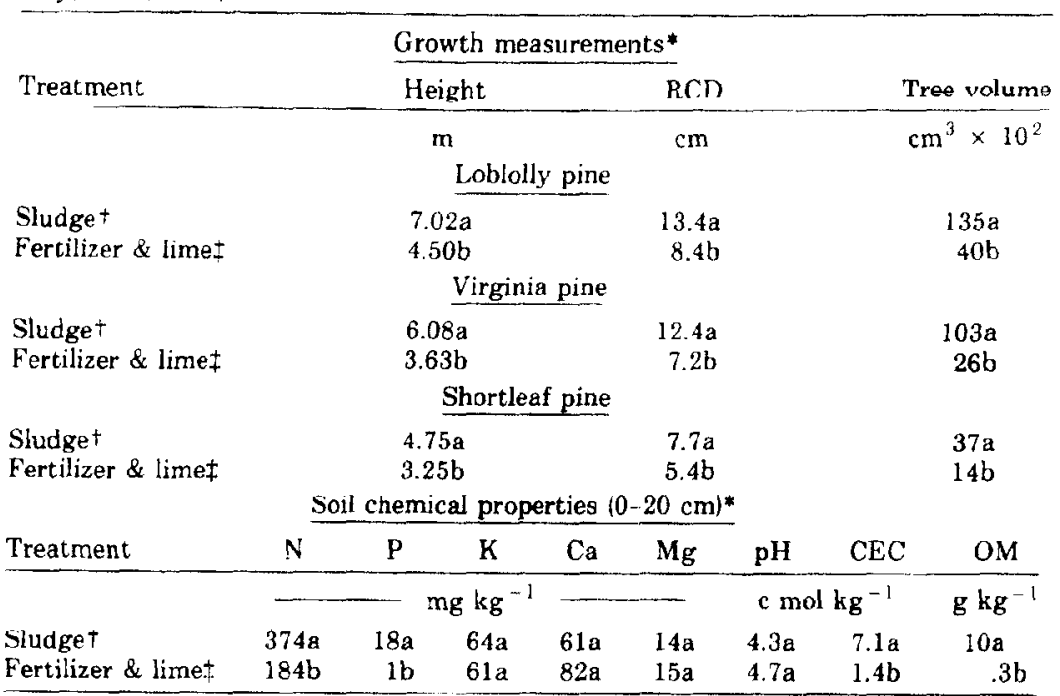

* Within columns and species, means sharing a common letter do not differ significantly at $P=0.05$.

$+34 \mathrm{Mg} \mathrm{ha}^{-1}$ (dry wt) dewatered sludge broadcast, subsoiled, disked, and planted.

$\$ 900 \mathrm{~kg} \mathrm{ha}^{-1}$ of $10-10 \cdot 10$ fertilizer and $1400 \mathrm{~kg} \mathrm{ha}^{-1} \mathrm{CaO}$ broadcast, subsoiled, disked, and planted.

sites on over two million hectares on the Piedmont Plateau in Alabama, Georgia, and South Carolina. Most littleleaf disease sites are void of topsoil, and exposed clays have poor internal drainage, low fertility, and low organic matter content. Berry (1977) subsoiled and applied solid sewage sludge to a high-hazard littleleaf disease site with the intent of eliminating soil edaphic factors contributing to the disease. Sludge from Athens, Georgia, was applied at $0,17,34$, and $68 \mathrm{Mg} \mathrm{ha}^{-1}, 1 \mathrm{yr}$ after subsoiling. Onc-half of the plots were subsoiled and all plots were disked. Midway through the first growing season after planting shortleaf and loblolly pine seedlings, growth of ragweed (Ambrosia spp.) and hairy crabgrass [Digitaria sanquinalis (L.) Scop.] was so great on the sludge plots that tree survival and productivity were minimal. Total weed biomass was five times greater on the high sludge plots than on controls. Effects of subsoiling could not be detected. This severely eroded littleleaf disease site was successfully revegetated by application of sludge, but the dominant plants were herbaceous plants or annuals rather than trees.

\section{TREE NURSERY APPLICATION}

Forest nurseries occupy approximately 3430 ha of land in the USA and produce two to threc billion tree seedlings each year. Particularly in the South, 
tree nurseries must maintain high soil organic matter and nutrient content to grow high-quality seedlings (Davey \& Krause, 1980). Sewage sludge is a good source of organic matter as well as nutrients. Many sludges, however, contain heavy metals and excessive amounts of salts that are potentially harmful to seedling growth (Bickelhaupt, 1980). Nevertheless, Berry (1981) obtained favorable results from a single application of $136 \mathrm{Mg} \mathrm{ha}^{-1}$ of dried sewage sludge in a Florida nursery. Slash pine $(P$. elliottii Englem. var. $e l-$ liottii) seedlings were larger with sludge application than with the standard nursery applications of fertilizer. Screened compost (sewage sludge composted with wood chips) was used in Maryland for the production of high-quality hardwood seedlings (Gouin \& Walker, 1977; Gouin et al., 1978). Bledsoe and Zasoski (1981) found that six conifers and two Populus species grew two to three times taller and produced two to five times more biomass in a soil/sludge mixture $(3: 1)$ than in soil alone.

Berry (1985) examined the nutritional and phytotoxic properties of several municipal sludges and their effects on ectomycorrhizal development and growth of loblolly pine in a microplot nursery test. He grew seedlings in fumigated soil amended with 34 or $68 \mathrm{Mg} \mathrm{ha}^{-1}$ of one of five sewage sludges: (i) old sludge from Achens, Georgia, (ii) fresh sludge from Athens, Georgia, and sludges of undetermined age from (iii) Aiken, South Carolina, (iv) Newberry, Florida, and (v) Chicago, Illinois. Newberry sludge and fresh Athens sludge supported growth comparable to the inorganic fertilizer control. Seedlings grown with Chicago sludge grew well at the $68 \mathrm{Mg} \mathrm{ha}^{-1}$ but were not as large as those grown with fertilizer. Seedlings grown with old Athens or Aiken sludge did not grow well and most of them were not of plantable size. Pisolithus tinctorius did not form ectomycorrhizae on seedlings grown with the sludges as well as on seedlings grown with fertilizer (in most cases $<23 \%$ of short roots compared to $63 \%$ for controls). Thelephora terrestris formed ectomycorrhizac as rcadily on seedlings grown with the sludges as those grown with fertilizer when inoculation with the fungus was artificial. Natural ectomycorrhizae formed by $T$. terrestris from airborne spores, however, did not form as readily with some sludges as with fertilizer.

Somewhat surprising, in most cases seedlings with the highest concentration of heavy metals in tissues were not from sludge with the highest concentration of the specific heavy metals. An exception to this trend, however, was $\mathrm{Cd}$. Its concentration was highest in seedlings grown with Chicago sludge, which had the highest concentration of $\mathrm{Cd}$ of all siudges tested. Zinc concentrations were high in seedlings grown in soil amended with Aiken sludge, which had the highest $\mathrm{Zn}$ concentration of any of the sludges. Chicago sludge, on the other hand, had virtually the same $\mathrm{Zn}$ content as Aiken sludge and induced growth of seedlings with significantly lower $\mathrm{Zn}$ concentrations in tissues.

During the one growing season of this study, $\mathrm{Cd}$ and $\mathrm{Zn}$ uptake by seedlings represented only about $1 \%$ of the amount present in the amended soil. Residual amounts remained high in soil. Berry (1985) concluded that municipal sewage sludges will support production of high quality tree secdlings and could be used to supply organic matter and nutrients. He cautioned, 
however, that the lack of detrimental concentrations of certain heavy metals should be confirmed.

\section{REGENERATION AND FOREST LAND APPLICATION}

In the Pacific Northwest and North Central Regions of the USA, improvements in tree growth on forest sites from sludge application are well documented (Bledsoe, 1981). For southern tree species, however, there is litthe information about optimal rates of sludge application, stand ages when sludge application is beneficial, site characteristics for highest growth response, or possible interactions with indigenous pests. Three sludge studies at the SRS in South Carolina are noteworthy.

Stone and Powers (1989) amended a good-quality regeneration site (Typic Kandiudults, Orangeburg soil series) with anaerobically digested liquid municipal sewage sludge. Application rates of 0,85 and $170 \mathrm{ML} \mathrm{ha}^{-1}$ provided total $\mathrm{N}$ at 0,336 , and $672 \mathrm{~kg} \mathrm{ha}^{-1}$. The low rate treatment contained $126,67,11,60,11$ and $4500 \mathrm{~kg} \mathrm{ha}^{-1}$ of $\mathrm{NH}_{4}-\mathrm{N}, \mathrm{P}, \mathrm{K}, \mathrm{Ca}, \mathrm{Mg}$, and organic matter, respectively; the high rate was twice these amounts. I.oblolly pine seedlings of two genetic sources, one resistant to fusiform rust [Cronartium quercuum (Berk) Miyabe ex Shirai f. sp. fusiforme] disease, were planted in the winter of 1981. Results of combined data for both sources of loblolly pine after $6 \mathrm{yr}$ were highly significant (Table 14-7). The sludge treatments increased height, diameter, and volume growth with no differences between the two sludge application rates. Associated with sludge treatments was increased competition from indigenous herbaceous vegetation which undoubtedly limited tree responses. Loblolly pine does not survive or grow well in its early years with dense competition from associated vegetation (Nelson et al., 1981; Knowe et al., 1985; Havu od \& Melder, 1982). An unexpected effect of sludge treatment was observed on the incidence of fusiform rust disease. Treatments decreased rust infection on seedlings of both the nurseryrun and the rust-resistant sources. Usually, cultural practices that stimulate seedling growth increase the incidence of rust disease on loblolly pine (Miller, 1977). Stone and Powers (1989) speculated that reduced disease associated

Table 14-7. Growth of loblolly pine after 6 yr on a good quality forest site amended with different amounts of liquid municipal sewage sludge (Stone \& Powers, 1989).

\begin{tabular}{lccc}
\hline Treatment & Height & DBH & Tree volume \\
& $\mathrm{m}$ & $\mathrm{cm}$ & $\mathrm{cm}^{3} \times 10^{2}$ \\
Control & $5.6 \mathrm{a}^{*}$ & $1.28 \mathrm{~b}$ & $9.5 \mathrm{~b}$ \\
$336 \mathrm{~kg} \mathrm{~N} \mathrm{ha}{ }^{-1}$ & $5.9 \mathrm{a}$ & $1.38 \mathrm{a}$ & $11.6 \mathrm{a}$ \\
$672 \mathrm{~kg} \mathrm{~N} \mathrm{ha}{ }^{-1} \ddagger$ & $5.9 \mathrm{a}$ & $1.40 \mathrm{a}$ & $12.0 \mathrm{a}$ \\
\hline
\end{tabular}

* Within columns, means sharing a common letter do not differ significantly at $P=0.05$.

† Anaerobically digested liquid municipal sewage sludge applied at approximately $85 \mathrm{ML}$. ha ${ }^{-1}$, disked and planted.

$\ddagger$ Anaerobically digested liquid municipal sewage sludge applied at approximately 170 MI. ha ${ }^{-1}$, disked and planted. 
with the sludge treatments may be due to changes in seedling physiology and susceptibility, or an interaction between increased herbaceous cover and reduced insect attack (Powers \& Stone, 1988).

- Kormanik and Berry (unpublished data) installed a solid sludge study with sweetgum on a forest site with Orangeburg soil. In July 1983, $34 \mathrm{Mg}$ $\mathrm{ha}^{-1}$ of sludge from Athens, Georgia, were applied; $280 \mathrm{~kg} \mathrm{ha}^{-1}$ diammonium phosphate were applied as the fertilizer treatment. In September, half of the amended and the control plots were subsoiled on 1.2 -m centers, 0.76 $m$ deep, and then all plots were disked. Sweetgum seedlings with or without endomycorrhizae were planted in the spring of 1984 . Various herbicides were applied prior to planting sweet gum but were not effective in controlling competing vegetation. Plots were disked periodically for the first few years after planting to control weeds and herbaceous competition. Results after $2 \mathrm{yr}$ were discussed by Berry (1987). Trees on both sludge and fertilizer plots were significantly larger than controls, but there were no differences in growth between the amendments. Trees on subsoiled plots also were significantly larger than those in disked plots when effects of soil amendments were combined. There was no effect of endomycorrhizal treatment. As in the other studies, soil chemical properties were significantly improved by applying sludge, even on this good-quality forest site (Table 14-8). Two years after application, there were no differences in soil analyses between the fertilizer and control treatments except for small differences in $K$. However, sludge plots had much higher soil concentrations of total $\mathrm{N}$, available $\mathrm{P}, \mathrm{K}$ and $\mathrm{Ca}$ and significantly higher CEC and organic matter. At age eight, the effect of sludge was still highly significant (Table 14-8), but the subsoiling ef fect was no longer evident. Sweetgum volume growth on sludge plots was twice that on fertilizer plots, and trees on control plots had less than half the volume of those

Table 14-8. Growth of sweetgum after 8 yr and soil chemical propertics after 2 yr on a good quality forest site amended with sludge or fertilizer (Berry, 1987; Kormanik \& Berry, unpublished datal.

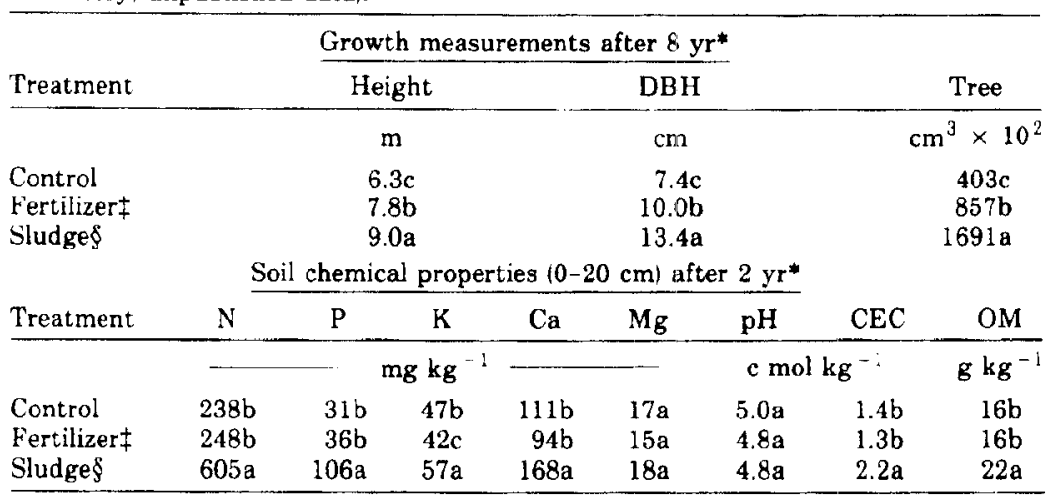

* Within columns, means sharing a common letter do not differ significantly at $P=0.05$. + Data from subsoiled vs. disking treatments combined for all amendments. $\pm 280 \mathrm{~kg} \mathrm{ha}^{-1}$ diammonium phosphate.

$\S 34 \mathrm{Mg} \mathrm{ha}^{-1}$ (dry wt) dewatered sludge broadcast (2.5-cm-deep layer) 
on fertilizer plots. Several different sweetgum biomass studies had been installed over the past $14 \mathrm{yr}$ at the SKS on the better quality upland soils. In all cases, the best fertilizer practices have yielded 8.9 to $13.4 \mathrm{~m}^{3} \mathrm{ha}^{-1} \mathrm{yr}^{-1}$ after $10 \mathrm{yr}$. This volume of biomass production compares favorably with that from intensive management of aldcr (Alitus spp.) and poplar (ropulus spp.) over 12- to 15 -yr rotations. It exceeds the $6.7 \mathrm{~m}^{3} \mathrm{ha}^{-1} \mathrm{yr}^{-1}$ averaged obtained with loblolly pine on all site types on $25-$ to $30-y r$ rotations. With sludge in this study, however, yields of almost $27 \mathrm{~m}^{3} \mathrm{ha}^{-1} \mathrm{yr}^{-1}$ were realized after only $8 \mathrm{yr}$. This is even more remarkable when one considers that sweetgum typically produces little volume for the first 2 to 3 yr after plant ing. Volume increases due to sludge in the last 5 to 6 yr of the study were tremendous.

The last sludge study we will discuss involved four ages of loblolly pine. The principal study objective was to evaluate alternative techniques for forest land disposal of sewage sludge. The goal was to increase biomass production in loblolly pine plantations without degrading the environment or wood quality. In 1980, single applications of $632 \mathrm{~kg} \mathrm{~N} \mathrm{ha}^{-1}$ in solid aerobic sludge or 0,402 , or $804 \mathrm{~kg} \mathrm{~N}^{-1}$ in a liquid anaerobic sludge were made in plots in $1-, 3-, 8-$, and 28 -yr-old loblolly pine stands. The liquid sludge contained $7 \%$ total $N$, the solid sludge contained $1.3 \%$ total $N$. Liquid sludge came from Augusta, Georgia, and the solid sludge came from Aiken County, South Carolina. Prior to sludge applications, all physical and chemical characteristics of the trees and soils were determined. Over a 5-yr period, several sub. jects were studied.

For brevity, we cite the comprehensive report by Davis and Corey (1989), which describes in detail the results obtained by the various authors. After $4 \mathrm{yr}$, low rates of $\mathrm{N}$ increased diameter and basal area growth of the 8- and 28 -yr-old trees. Higher rates did not result in greater increase. Solid sludge did not improve growth of the 28-yr-old trees. Solid and liquid sludge applied at plantation established (i.e., 1-yr-old) increased growth only modestly. Growth stimulation depended on control of insects and competing vegetation and incorporation of the sludge by disking. Incorporated solid sludge improved plantation establishment. Three-year-old trees did not respond to any sludge treatment, probably because competition from associaied vegetation was intense. Liquid sludge reduced specific gravity of early wood in 8- and 28-yr-old trees but did not significantly change wood quality. Understory biomass production was increased by sludge applications in plantaiions of all ages. The herbaceous component showed the greatest response.

With a few exemptions, sludge treatments did not result in nitrate or heavy metal leaching into groundwater. Content of $\mathrm{NO}_{3}-\mathrm{N}$ in soil water exceeded $60 \mathrm{mg} \mathrm{L}^{-1}$ at 1 -m depth 4 mo after $800 \mathrm{~kg} \mathrm{~N}$ ha $^{-1}$ were applied to plantations at age 0 and 28. Liquid sludge application of $400 \mathrm{~kg} \mathrm{~N}^{-1}$ or solid-sludge application of $630 \mathrm{~kg} \mathrm{~N}$ ha ${ }^{-1}$ did not increase $\mathrm{NO}_{3}-\mathrm{N}$ above the $10 \mathrm{mg} \mathrm{kg}^{-1}$ standard for water quality in the $3-, 8$, and 28 -yr-old stands. Nitrate-nitrogen was lower in stemflow, i.e., water flowing down stems, than in bulk prccipitation or in throughfall. Ammonium-nitrogen was higher in stemnlow of control plots than in any other samples except the high 
liquid treatment. In the 8- and 28-yr-old plots, both rates of liquid sludge increased litterfall weigh: 20 to $30 \%$ over control and solid-sludge treatments. Eighteen months after application, over $20 \%$ of the $\mathrm{N}$ from liquid sludge was in the forest floor of the 8 -yr-cld stand, $30 \%$ was in the forest floor of the 28-yr-old stand. In the 28-yr-old stand treated with solid-sludge, $67 \%$ of the $\mathrm{N}$ remained in the forest floor. The $\mathrm{N}$ increase in the forest floor of the 8-yr-old stand was caused by increased litterfall and understory development since there was little forest floor present at time of sludge application. The high retention percentage in the forest floor of the 28-yr-old stand is attributed to the presence of a well-established forest floor at time of application.

Eighteen months after treatment, the 8-yr-old stand had 40 to $70 \%$ of the $\mathrm{Zn}, \mathrm{Cu}, \mathrm{Pb}, \mathrm{Ni}, \mathrm{Cd}$, and $\mathrm{Cr}$ from the liquid sludge in the forest floor. From 50 to $100 \%$ of these elements from liquid sludge were found in the forest floor of the 28-yr-old stand. The latter also contained 55 to $66 \%$ of these heavy metals from solid sludge.

Measurements of $\mathrm{N}$ availability in the 28-yr-old stand showed that concentrations in foliage, wood, fine roots, and needlefall all increased after sludge applications. Litterfall dry weight, total aboveground production, and $\mathrm{N}$ in litterfall were positively correlated with $\mathrm{N}$ availability. Nitrogen use efficiency decreased with sludge additions.

Sludge applications also affected soil biology. Soil mesofauna populations were reduced by liquid sludge in all stands, while solid sludge increased populations in the 28 -yr-old stand. Low rates of sludge application increased cellulase activity while high rates decreased it.

Davis and Corey (1989) concluded that liquid sludge at rates of $400 \mathrm{~kg}$ $\mathrm{N}$ ha ${ }^{-1}$ or less is an effective silvicultural treatment to fertilize pulp and sawtimber stands of loblolly pine. Forest productivity was without significant environmental or wood-quality degradation. They suggested that pulpwood rotations could be shortened with low-level sludge applications at ages 8 to 10 and 12 to 14. Applications to young sawtimber (the 28 -yr-old stand) could be made every 3 to $5 \mathrm{yr}$. Applications to stands less than $8 \mathrm{yr}$ old (before crown closure) would dispose of sludge but would stimulate competing vegetation so much that rates of tree growth would decrease.

\section{CONCLUSIONS}

Application of liquid and solid municipal sewage sludge to forests and degraded lands has been studied extensively. The results clearly show that these properly applied and monitored treatments can physically, chemical$l y$, and biologically rehabilitate degraded lands. They also can increase productivity on regeneration sites and on established tree plantations. Depending on goals, competing vegetation may have to be controlled. Tremendous quantities of sludge could be recycled through the vast areas of forests and degraded land of the USA. Much of this land is close enough to municipalities for practical hauling of sludge. Recycling of the organic matter and 
the inorganic nutrients in sludge would eliminate a hugh waste disposal problem now faced by municipalities. Concerns over land application of sludges containing significant amounts of heavy metals undoubtedly will continue to be an issue. However, application of such sludges into degraded or forest soils greatly reduces the likelihood of these heavy metals entering the human and animal food chains. Application of these sludges to food crops or their disposal into landfills dues not furnish these safeguards. Logic suggests that these nutrient-rich wastes should be applied to forests and degraded land. This approach of fers environmentally sound recycling of the wastes and it enhances forest and soil productivity.

\section{REFERENCES}

Bastian, R.K., A. Montague, and T. Numbers. 1982. The potential for using municipal wastewater and sludge in land reclamation and biomass production as an I/A technology: An over. view, p. 13-54. in W.E. Sopper et al. (ed.) I and reclamation and biomass production with municipal wastewater and sludge. Pennsylvania State Univ. Press, Univ. Park, PA.

Berry, C.R. 1977. Initial response of pine seedlings and weeds to dried sewage sludge in rehabilitation of an eroded forest site. USDA-FS Note SE-249. USDA-FS, Asheville, NC

Berry, C.R. 1979. Slit applieation of fertilizes tablets and sewage sludge improve initial growth of loblolly pine seedlings in the Tennessee Copper Basin. Reclam. Rev. 2;33-38.

Berry, C.R. 1981. Sewage sludge effects soil properties and growth of slash pine seedlings in a Florida nursery. p. 46-51. In Proc. Southern Nursery Conf., Lake Barkeley, KY. 2-4 Sept. 1980. Tech. Publ. SE-TP-17. USDA-FS State \& Private Forestry, Atlanta, GA.

Berry, C.R. 1982. Dried sewage sludge improves growth of pines in the Tennessee Copper Basin. Reclam. Reveg. Res. 1:195-201.

Berry, C.R. 1985. Subsoiling and sewage sludge aid loblolly pine establishment on adverse sites. Reclam. Reveg Res, 3:301-311.

Berry, C.R. 1987. Use of municipal sewage sludge for improvement of forest sites in the Southeast. USDA-FS Res. Pap. SE-266. USDA-FS, Asheville, NC.

Berry, C.R., and D.H. Marx. 1978. Effects of Pisolith is tinctorius ectomycorrhizae on growth of loblolly and Virginia pines in Tennessee Copper Basin. USDA-FS Res. Note SE-264. UISDA-FS, Asheville, NC.

Berry, C.R., and D.H. Marx. 1980. Significance of various soil amendments to borrow pit reclamation with loblolly pine and fescue. Reclam. Reveg. Res. 3:87-94.

Bickelhaupt, D.H. 1980. Potential hazards of some organic wastes that may be used in nurseries. p. 166-173. In Proc. Workshop North Am. Forest Trec Nurscry Suils. Syracuse, NY. 28 July-1 August. USDA-FS, Canadian For. Serv, and State Univ. of New York

Blauch, E.W. 1978. Reclamation of lands disturbed by stone quarries, sand and gravel pits and borrow pits. p. 6[9-628. In R.W. Schaller, and P. Sutton (ed.) Reclamation of drastically disturbed lands. ASA, CSSA, and SSSA, Madison, WI

Bicdsoe, C.D., and R.J. Zasoski. 1981. Seedling physiology of eight tree species grown in sludge amended soils. p. 93-100. In C.S. Bledsoe (ed.) Municipal sludge application to Pacific Northwest forest lands. Proc. Symp., Seatle, W A. 8-10 July 1980. College For. Resour., Univ. Washington, Seattle.

Bledsoe, C.S (ed.) 1981. Municipal sludge application to Pacific Northwest forest lands. Proc. Symp., Seattle, WA. 8-10 July 1980. College For. Resour., Univ. Washington, Seattle.

Cole, D.W.. C.L. Henry, W.L. Nutter (ed.) 1986. The forest alternative for treatment and urilization of municipal and industrial wastes. Proc. Symp., Seattle, WA. 25-28 June 1985. College For. Resour., Univ. Washington, Seattle

Cole. D.W., C.L. Henry, P. Schiess, and R.J. Zasoski. 1983. Forest systems. p. 125-143. In A.L. Page et al. (ed.) Proc. Workshop Utilizatio., Wastewater and Sludge on land, Univ. of California, Riverside.

Davey, C.B., and H.H. Krause. 1980. Functions and maintenance of organic matter in forest nursery soils. p. 130-145. In Proc. Workshop, North Am. Forest Tree Nursery Soils. Syracuse, NY. 28 July-1 August. USDA-FS, Canadian For. Serv., and State Univ. of New York. 
Davis, C.E., and J.C. Corey. 1989. Fores land application of sewage sludge on the Savannah River Plant (U.). DP-1763. Westinghouse Savannah River Co., Aiken, SC.

Gouin. F.R., C.B. Link, and J.F. Kundt. 1978. Forest seedlings thrive on composted sludge. Compost Sci. Land Util. 19:28-30.

Gouin, F.R., and J.M. Walker. 1977. Deciduous tree seedlings response to nursery a $\mathrm{c}^{: 1}$ amendcd with composted sewage sludge. Hort. Sci. 12:45-47.

Granade, G.V. 1976. Soil changes and plant response to lime and fertilizer on reseeded borrow pits. M.S. thesis. Univ. of Georgia, Athens.

Haywood, J.D., and T.W. Melder. 1982. How site treatments affect pine and competing plant cover. p. 224-230. In Proc. South. Weed Sci. Soc., New perspectives in weed science, A1lanta, GA. 19-21 January. WSSA, Champaign, IL.

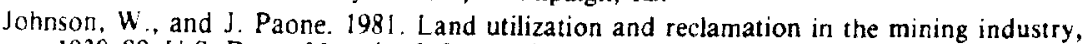
1930-80. U.S. Dep. of Interior Inform. Circ. 8862. U.S. Gov. Print Office, Washington, DC.

Knowe, S.A., L.R. Nelson, D.H. Gierstad, B.R. Zutter, C.R. Glover, P.I. Minogue, and J.H. Dukes, Jr. 1985 . Four-year growth and development of planted loblolly pine on sites with competition control. South. J. Appl. For. 9:11-15.

Kormanik, P.P. 1990. Liquidambar styraciflua L. p. 400-405. In R.M. Burns and B. H. Honkala (ed) Silvics of North America. Vol 2. USDA-FS Agric. Handb. 654. U.S. Govi. Print. Office, Washington, DC.

Kormanik, P.P., and R.C. Schultz. 1985. Significance of sewage sludge amendments to bortow pil reclamation with sweetgum and fescue. USDA-FS Res. Note SE-329. USDA-FS, A sheville, NC.

Marx, D.H., C.E. Cordeil, D.S. Kenney, J.G. Mexal, J.D. Artman, J.W. Riffle, and R. Molina. 1984. Commercial vegetative inoculum of Pisolithus tinciorius and inoculation techniques for development of ectomycorrhizae on bare root tree seedlings. For. Sci. Monogr.

McGregor, W.H.D., and N.B. Goebel. 1968. Effectiveness of nitrogen fertilizers and mulch for the amelioration of severe planting sites. p. 65-72. In C.H. Youngherg and C.B. Davey (ed.) Proc. 3rd North Am. For. Soils Conf., Oregon State Univ. Press, Corvallis.

McNab, W.H., and C.R. Berry. 1985. Distribution of aboveground biomass in three pine species planted on a devastared site amended with sewage sludge or inorganic fertilizer. For. Sci. $31: 373-382$

Miller, T. 1977. Fusiform rust management strategies in concept. p. 110-115. In R.J. Dinus and R.A. Schmidı (ed.) Proc. Symp. Manage. of Fusiform Rust in Southern Pines, Gainesville. FL. 7-8 Dec. 1976. USDA-FS, Atlanta, GA.

Nelson. L.R., R.C. Pedersen, L.L. Autry, S. Dudley, and I.D. Walstad. 1981. Impacts of herbaceous weeds in young loblolly pine plantations. South. J. Appl. For 5:153-158.

Otrosina. W.J., and D. H. Marx. 1975. Ponulations of Phytophehora cinnamomi and Pythium spp. under shortleaf and loblolly pines in littleleaf disease sites. Phytopathology 65:1224-1229.

Powell, D.S., J.L. Faulkner, D.R. Darr, Z. Zhu, and D. W. MacCleery. 1993 Forest Resources of the United States, 1992. USDA-FS Rocky Mountain For, and Range Exp. Stn., Gen. Tech. Rep. RM-234.

Powers, H.R. Jr., and D.M. Stone. 1988. Control of tip moth by carbofuran reduces fusiform rust infection on loblolly pine. USDA-FS Res. Paper SE-270. USDA-FS, Asheville, NC.

Ruehle, J.L. 1980. Growth of containerized loblolly pine with specific ectomycorrhizae after 2 years on an amended borrow pit. Reclam. Rev. 3:95 101 .

Smith. W.H., and J.O. Evans. 1977. Special opportunities and problems in using forest soils for organic waste application. p. 429-454. In J.F. Elliott and F.J. Stevenson (ed.) Soils for management of organic works and waste waters. ASA, CSSA, and SSSA, Madison, W1.

Sopper, W.E. 1992. Reclamation of mine land using municipal sludge. p. 351-431. R. Lal and B.A. Stewart (ed.) Advances in soil science. Vol 17. Springer-Verlag, New York.

Sopper, W.E., and L.T. Kardos. (ed.) 1973. Recycling treated municipal wastewater and sludge through forest cropland. Proc. Sympos., University Park, PA. 21-24 Aug. 1972. Pennsylvania State Univ. Press, University Park, PA.

Stone, D.M., and H.R. Powers. 1989. Sewage sludge increases early growth and decreases fusiform rust infection of nursery-run and rust resistant loblolly pine. South. I. Appl. For. 13:68-71.

U.S. Department of Interior. 1992. Surface coal mining reclamation: 15 years of progress 1977-1992. Part I. U.S Gov. Print. Office, Washington, DC. 